\title{
The occurrence of Culicoides species, the vectors of arboviruses, at selected trap sites in Zimbabwe
}

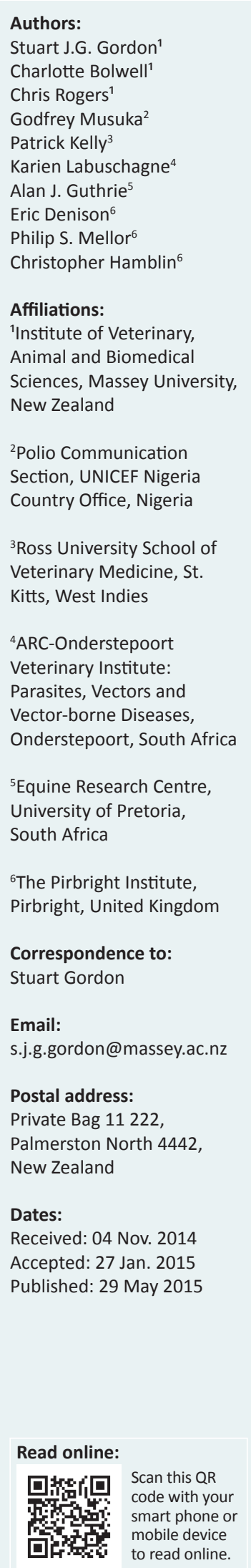

A study of the distribution of Culicoides species was conducted by establishing 12 light trap sites over five rainy seasons between 1998 and 2003 covering all the geo-climatic natural regions of Zimbabwe. In total, 279919 specimens of Culicoides were trapped over a total of 163 trapping nights. The highest median counts of Culicoides per trapping night were recorded in natural region III, which has climatic conditions conducive to the successful development of the larvae. Culicoides imicola, the major vector of bluetongue and African horse sickness viruses in Africa, was found to be the most abundant species (80.4\%), followed by Culicoides enderleini (5.9\%) and Culicoides milnei (5.2\%). This study identified 10 species of Culicoides that had not been previously described in Zimbabwe, including Culicoides loxodontis and Culicoides miombo, which are members of the $C$. imicola complex. A total of 23994 Culicoides midges were collected from five trap sites in Harare, Zimbabwe, with the dominant species, C. imicola, representing $91.6 \%$ of the total collection. Seventeen arboviruses were isolated from these midges, 15 of which were bluetongue virus. The predominant bluetongue virus serotype was serotype 11, followed by serotypes 1, 8, 12 and 15. Bluetongue virus serotypes 1, 2, 8, 10, 12, 15, 16 and 18, detected in this study, had not been previously reported in Zimbabwe.

\section{Introduction}

African horse sickness virus (AHSV), which infects all equine species, and bluetongue virus (BTV), which infects sheep and other ruminants, are endemic in Zimbabwe. High seroprevalences of AHSV in horses and donkeys and BTV in cattle and sheep were reported throughout Zimbabwe (Gordon 2010), with mortality rates because of African horse sickness and bluetongue reaching 95\% (Coetzer \& Guthrie 2004) and 33\% (Musuka 1999) respectively. Based on their economic importance and capacity to spread rapidly between countries, the World Organisation for Animal Health (OIE) has designated both these diseases as notifiable animal diseases. Equine encephalosis virus (EEV), which infects all equine species, and epizootic haemorrhagic disease virus (EHDV), which infects domestic and wild ruminants, have also been detected in Zimbabwe (Gordon 2010; Musuka 1999; Paweska et al. 1999). Many of these viruses are also enzootic in neighbouring countries, namely Botswana (Mushi et al. 1998), Zambia (Mweene et al. 1996), Namibia and South Africa (Meiswinkel, Venter \& Nevill 2004; Scacchia et al. 2009; World Organisation for Animal Health 2011). Oura et al. (2012) recently documented EEV in Ethiopia, Ghana, Gambia and Israel. Bluetongue today has a nearly worldwide distribution.

All of these diseases are caused by double-stranded ribonucleic acid (dsRNA) viruses of the family Reoviridae and genus Orbivirus, which are transmitted almost exclusively by Culicoides (Diptera: Ceratopogonidae) biting midges (Meiswinkel et al. 2004; Mellor, Boorman \& Baylis 2000). Culicoides imicola and Culicoides bolitinos have been identified as vectors of AHSV and are widely distributed in sub-Saharan Africa (Meiswinkel \& Paweska 2003; Mellor 1993). Culicoides bolitinos has also been implicated as an important potential vector of EEV and BTV in South Africa (Meiswinkel \& Paweska 1998, 2003; Venter et al. 2002).

Previous studies in Zimbabwe found C. imicola to be the most abundant livestock-associated Culicoides species, followed by Culicoides zuluensis (Blackburn, Searle \& Phelps 1985; Braverman \& Phelps 1981; Braverman et al. 1985; Gordon 2010; Musuka 1999; Musuka, Chihota \& Kelly 1998; Phelps, Blackburn \& Searle 1982). The vector competence of most Culicoides species in Zimbabwe has not been studied in detail and other species may, in future, be identified as vectors of these viruses.

How to cite this article: Gordon, S.J.G., Bolwell, C., Rogers, C., Musuka, G., Kelly, P., Labuschagne K. et al., 'The occurrence of Culicoides species, the vectors of arboviruses, at selected trap sites in Zimbabwe', Onderstepoort Journal of Veterinary Research 82(1), Art. \#900, 8 pages. http://dx.doi.org/10.4102/ojvr.v82i1.900

Copyright: @ 2015. The Authors. Licensee: AOSIS OpenJournals. This work is licensed under the Creative Commons Attribution License. 
Agro-ecological classification, known as natural region (NR) classification in Zimbabwe, divides the country into five regions based on mean annual rainfall (Vincent \& Thomas 1960). The aim of this study was to identify the species of Culicoides distributed across these regions during the period 1998-2003. It is known that climate has a profound influence on the viability and fecundity of the Culicoides midges (Mellor 1993). To date no differences in disease abundance have been reported between these regions. The monthly abundance and distribution of Culicoides species in these five regions was, therefore, determined. In addition, this study aimed to isolate and identify arboviruses isolated from Culicoides midges collected in Harare over 7 days within the study period. Such studies will expand our knowledge of the biology of Zimbabwean Culicoides species and the potential for transmission of viral pathogens. This information will help assess the risks to both ruminant and equine livestock in Zimbabwe attributable to the presence of the Culicoides vector and hence the implementation of appropriate integrated control strategies (Rawlings et al. 1998).

\section{Materials and methods}

\section{Selection of Culicoides trap sites in Zimbabwe}

Culicoides midges were collected from a convenience sample of 12 trap sites in Zimbabwe. Collections were made over five consecutive rainy seasons (November-April) from 1998 to 2003. Collection site selection was based on several criteria, including: a minimum number of either horses or ruminants (> 8); historical presence of clinical disease or deaths in animals; presence of suitable Culicoides vector breeding conditions (e.g. low-lying areas, such as river banks or marshy fields, with clay soils); security of the equipment; and the availability of an alternating $220 \mathrm{~V}$ current power supply. Trap sites were distributed to include each of the five NRs of Zimbabwe (Figure 1). Two trapping sites were established in NR I, six in NR II, one in NR III, two in NR IV and one in NR V. Twenty-four individual collections (trapping nights) were made from NR I, 109 from NR II, 18 from NR III and 9 from NR IV across the five rainy seasons. Trapping was to be conducted for one night every 2 weeks during each rainy season, although this protocol was not followed consistently at each trapping site. Only three individual collections were made in NR V during the entire period under study.

Rainfall is highest in NR I (> $1050 \mathrm{~mm}$ per annum) whilst NR II and III contain the most arable land and receive $500 \mathrm{~mm}-1050 \mathrm{~mm}$ of rain per annum. NR I is a specialised and diversified farming region with plantation forestry, fruit and intensive livestock production, whilst NRs II and III are suitable for intensive farming based on crops and livestock production. Severe mid-season dry spells

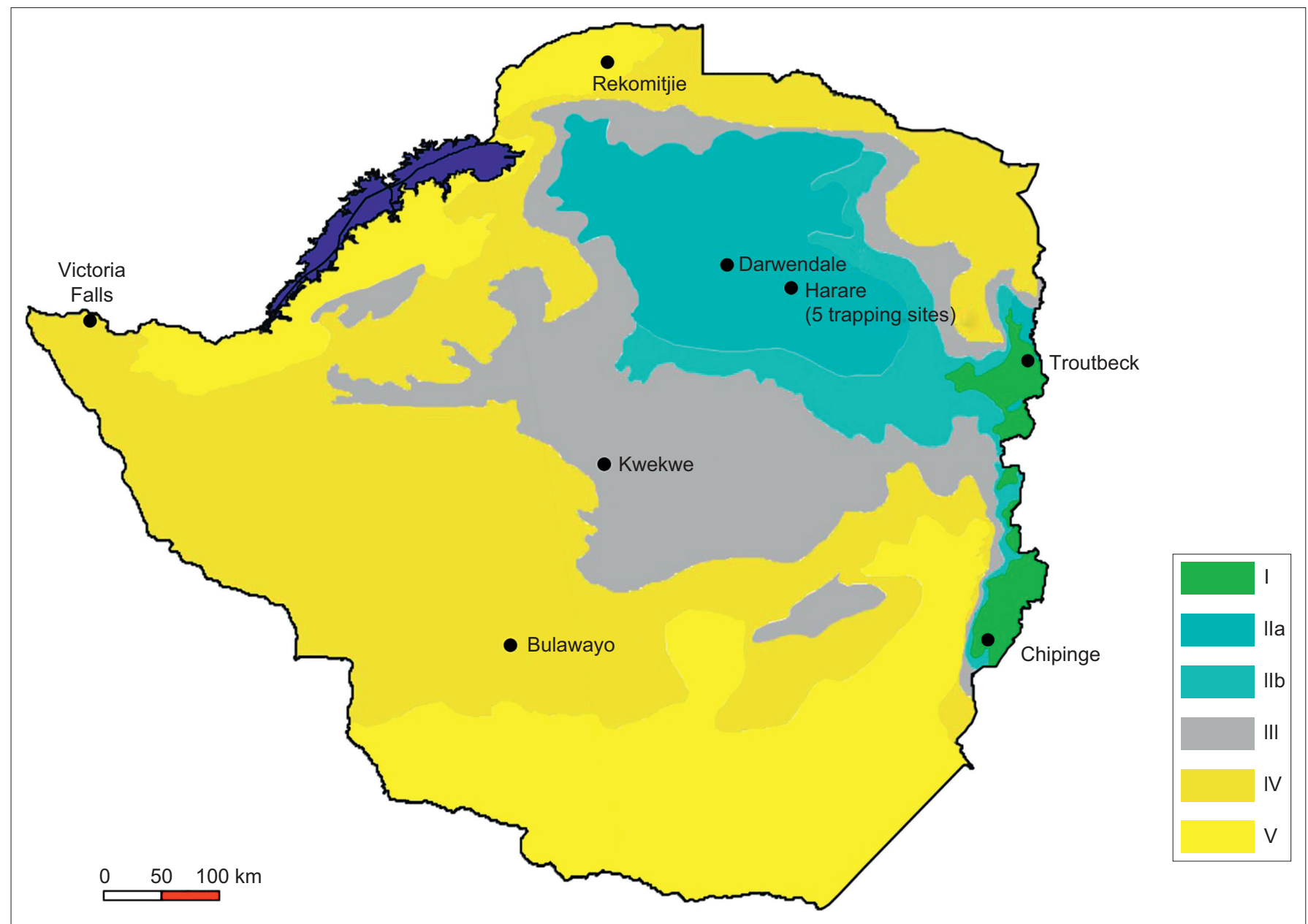

FIGURE 1: The natural regions of Zimbabwe and the locations of the 12 Culicoides trapping sites. 
make NR III marginal for maize, tobacco and cotton, or for enterprises based on crop production alone. The farming systems, therefore, are based on both livestock (assisted by the production of fodder crops) and cash crops. NR IV and $\mathrm{V}$ have a lower annual rainfall $(<600 \mathrm{~mm}$ per annum) and experience periodic seasonal droughts and/or severe dry spells during the rainy season. The farming, therefore, is based on extensive livestock ranching and drought-resistant fodder crops (Vincent \& Thomas 1960).

\section{Trapping, sorting and processing of Culicoides samples for identification}

Dusk (18:00) till dawn (06:00) trapping was conducted at each trap site using Onderstepoort $220 \mathrm{~V}$ down draught suction light traps each fitted with an $8 \mathrm{~W}$ black fluorescent (ultraviolet) light tube. The traps were hung on the branches of trees or on the eaves of buildings approximately $1.4 \mathrm{~m}$ above ground level and within close proximity to the animals. Culicoides midges were collected into phosphate-buffered saline (PBS) and $0.5 \%$ chlorhexidine (Savlon ${ }^{\circledR}$, Novartis, U.K.). After collection specimens were re-suspended and preserved in $80 \%$ ethyl alcohol and stored in the dark at room temperature until sorted, identified and counted.

Species were identified and counted under a binocular dissecting microscope using a wing pattern atlas of southern African Culicoides species (R. Meiswinkel, unpublished atlas 1996). For large collections in excess of 1000 midges, the total numbers were estimated by measurement of a minimum of five $1 \mathrm{~mL}$ subsamples according to the protocol of Van Ark and Meiswinkel (1992).

\section{Trapping and sorting of Culicoides midges in Harare for virus isolation}

Culicoides midges were collected for virus isolation at five sites around Harare (17 $51^{\prime} 50^{\prime} \mathrm{S}, 31^{\circ} 1^{\prime} 47^{\prime} \mathrm{E}$, located in NR II) using the method described above. These five Harare sites formed part of the 12 trappings mentioned previously. These Culicoides species were age graded according to the method described by Dyce (1969). Harare is $1508 \mathrm{~m}$ above sea level and situated in the northeast highveld of Zimbabwe. It is characterised by moderate subtropical conditions with an average monthly rainfall of $120 \mathrm{~mm}$ and air temperature between $15^{\circ} \mathrm{C}$ and $27^{\circ} \mathrm{C}$. All trap sites were on smallholdings with vertisol soil types and mixed forest vegetation where urban-intensive farming was practised. The main species of livestock were cattle, goats, sheep and horses.
The traps were hung from branches or eaves of buildings within close proximity to animal premises. All sites' traps were operated from dusk (18:00) to dawn (06:00) for seven consecutive days in March 2003. Culicoides were collected into a phosphate-buffered saline (PBS) solution containing $100 \mathrm{mg} / \mathrm{mL}$ of gentamicin and $0.1 \%$ chlorhexidine (Savlon ${ }^{\circledR}$, Novartis, U.K.) and stored at $4{ }^{\circ} \mathrm{C}$ until processed.

Individual species of Culicoides were stored at $4{ }^{\circ} \mathrm{C}$ in $2 \mathrm{~mL}$ Eppendorf tubes (a maximum of 50 flies per Eppendorf tube) with $1 \mathrm{~mL}$ of PBS containing $100 \mathrm{mg} / \mathrm{mL}$ of gentamicin and $0.1 \%$ chlorhexidine (Savlon ${ }^{\circledR}$, Novartis, U.K.). For each species or species group, the Culicoides specimens were sorted into the following categories: males, blood engorged females, non-engorged nulliparous females and non-engorged parous females, according to Dyce (1969).

\section{Preparation of Culicoides specimens for virus isolation and identification}

Midges were grouped into individual pools of up to 100 nonengorged females of each species. Each pool was homogenised in a mortar using a pestle with $1 \mathrm{~mL}$ of Eagles maintenance medium containing $1 \%$ foetal calf serum and antibiotics, using a modification of the technique proposed by El Hussein et al. (1989). Each homogenate was subsequently titrated for infectious virus in BHK-21 cells, brains from suckling mice and 11-day-old embryonated hens' eggs. Virus isolates were characterised using serogroup-specific, indirect, sandwich enzyme-linked immunosorbent assay (ELISA) for BTV (Thevasagayam et al. 1996), AHSV (Hamblin, Mellor \& Boned 1991), EEV (Crafford et al. 2003) and EHDV (Thevasagayam et al. 1996) antigens. The BTV isolates were subsequently serotyped using virus neutralisation index assays (Hazrati \& Ozawa 1965).

\section{Results}

\section{Collection of Culicoides across Zimbabwe for species identification}

A total of 279919 specimens of Culicoides, representing 51 different species, were trapped across Zimbabwe over five rainy seasons. Table 1 shows the numbers of Culicoides trapped per night in each NR of Zimbabwe and are reported as median values with interquartile ranges (IQRs). The distribution of each of the 10 most abundant Culicoides within the NR are presented as percentage values in Table 2 . The trap sites located in NR III recorded the highest median count of Culicoides species (1376 [IQR 286-1980]), followed by

TABLE 1: Median (and interquartile ranges) counts of Culicoides midges per trapping night caught in the five natural regions of Zimbabwe across five rainy seasons: 1998-2003 (November-April).

\begin{tabular}{|c|c|c|c|c|c|}
\hline Number & $\begin{array}{l}\text { Number of established } \\
\text { trapping sites }\end{array}$ & $\begin{array}{l}\text { Total number of individual } \\
\text { collections (trapping nights) }\end{array}$ & $\begin{array}{c}\text { Median (IQR) counts of } \\
\text { Culicoides per trapping night }\end{array}$ & $\begin{array}{c}\text { Minimum number of } \\
\text { Culicoides per trapping night }\end{array}$ & $\begin{array}{c}\text { Maximum number of } \\
\text { Culicoides per trapping night }\end{array}$ \\
\hline 1 & 2 & 24 & $5(1-25)$ & 0 & 1320 \\
\hline II & 6 & 109 & $125(37-678)$ & 0 & 10473 \\
\hline IV & 2 & 9 & 821 (175-918) & 56 & 8037 \\
\hline V & 1 & 3 & $255(148-3461)$ & 148 & 3461 \\
\hline
\end{tabular}

NR, natural region; IQR, interquartile range. 
TABLE 2: The mean percentage of the 10 most abundant Culicoides spp. trapped in each natural region in Zimbabwe over the five rainy seasons (1998-2003).

\begin{tabular}{lcccccc}
\hline Culicoides species & \multicolumn{7}{c}{ Natural region (\%) } \\
\cline { 2 - 7 } & I & II & III & IV & V & Total \\
\hline C. imicola & 84.7 & 80.2 & 81.7 & 85.0 & 2.7 & 80.4 \\
C. enderleini & 2.3 & 2.5 & 6.2 & 5.3 & 75.6 & 5.9 \\
C. milnei & 0.8 & 14.2 & 1.2 & 0.7 & 0.0 & 5.2 \\
C. zuluensis & 2.6 & 1.4 & 7.1 & 0.0 & 0.0 & 4.8 \\
C. nevilli & 0.0 & 0.2 & 1.8 & 0.03 & 0.0 & 1.2 \\
C. leucostictus & 0.04 & 0.2 & 0.5 & 0.06 & 0.0 & 0.4 \\
C. miombo & 3.9 & 0.03 & 0.0 & 5.4 & 3.4 & 0.4 \\
C. pycnostictus & 0.04 & 0.4 & 0.3 & 0.0 & 0.0 & 0.3 \\
C. bolitinos & 0.1 & 0.2 & 0.2 & 0.2 & 5.7 & 0.3 \\
C. subschultzei & 0.0 & 0.03 & 0.2 & 0.9 & 0.5 & 0.2 \\
\hline C. Culicoides. & & & & & &
\end{tabular}

C., Culicoides.

TABLE 3: The distribution of previously unreported species of Culicoides across the five natural regions of Zimbabwe (1998-2003).

\begin{tabular}{lccccc}
\hline Culicoides spp. & \multicolumn{5}{c}{ NR } \\
\cline { 2 - 6 } & $\mathrm{I}$ & $\mathrm{II}$ & $\mathrm{III}$ & $\mathrm{IV}$ & $\mathrm{V}$ \\
\hline $\begin{array}{l}\text { C. sp. \# } 107 \text { (provisionally given the } \\
\text { name C. kwagga by Meiswinkel } \\
\text { [1995] but not officially described) }\end{array}$ & - & $\mathrm{V}$ & - & $\mathrm{V}$ & - \\
C. glabripennis & & & & & \\
C. kerichoensis & - & $\mathrm{V}$ & - & - & $\mathrm{V}$ \\
C. loxodontis & $\mathrm{V}$ & - & - & - & - \\
C. miombo & - & $\mathrm{V}$ & - & $\mathrm{V}$ & $\mathrm{V}$ \\
C. moreli & $\mathrm{V}$ & $\mathrm{V}$ & - & $\mathrm{V}$ & $\mathrm{V}$ \\
nr. angolensis (species closely & - & - & - & $\mathrm{V}$ & - \\
associated with C. angolensis) & $\mathrm{V}$ & - & - & - & - \\
C. ovalis & & & & & \\
C. shimoniensis & $\mathrm{V}$ & - & - & - & - \\
C. trifasciellus & - & - & $\mathrm{V}$ & - & - \\
\hline
\end{tabular}

C., Culicoides; NR, natural region.

those trap sites located in NR IV (821 [IQR 175-918]). A full list of the different Culicoides trapped (in order of abundance) across the five NRs of Zimbabwe between 1998 and 2003 is shown as supplementary data in Appendix 1 (Table 1-A1).

The predominant Culicoides species trapped was C. imicola $(80.4 \%)$, followed by Culicoides enderleini $(5.9 \%)$, Culicoides milnei $(5.2 \%)$ and C. zuluensis (4.8\%). Culicoides imicola was the most abundant species trapped in NR I-IV, with C. enderleini being the most abundant species trapped in NR $\mathrm{V}$. The second most abundant species trapped in each NR was Culicoides miombo (NR I), C. milnei (NR II), C. zuluensis (NR III), C. miombo (NR IV) and C. bolitinos (NR V). Species of Culicoides found in every NR were C. imicola, C. enderleini, C. bolitinos and Culicoides subschultzei. Ten additional species, which have not previously been recorded in Zimbabwe, were collected (Table 3), bringing the total number of Culicoides species recognised in Zimbabwe to 60 .

\section{Collection of Culicoides in Harare for species identification and virus isolation}

A total of 23994 Culicoides specimens were collected from the Harare sites. Culicoides imicola (21 986/23 994; 91.6\%) was the most prevalent of the 26 species captured, followed by C. enderleini (1556/23 994; 6.5\%). Other species of Culicoides regularly captured at Harare were C. zuluensis (248/23 994;
1.0\%), C. bolitinos (70/23 994; 0.3\%) and Culicoides brucei (39/23 994; 0.2\%). Three species novel to Zimbabwe, namely C. miombo, Culicoides glabripennis and a specimen from the Nigripennis group, were identified in the Harare collections. Significant differences were found in the numbers of Culicoides midges collected at the five Harare trapping sites. Nearly $90 \%$ of all the specimens collected were from eight collections made at one of the sites at a horse stud. However, the greatest species diversity was observed at a different horse stud (17 different species). The lowest numbers of Culicoides and lowest species diversity were found at a dairy farm on the outskirts of Harare that had cattle only and no horses (196 midges belonging to eight species of Culicoides).

In the Harare study, 222 samples of non-engorged parous female Culicoides were assayed for BTV, AHSV, EEV and EHDV. A total of 17 Orbiviruses were isolated: 15 BTV and 2 EEV. Fourteen isolates of BTV were made from C. imicola and one from Culicoides magnus. Both the EEV isolates were from C. imicola. No AHSV or EHDV were isolated. Nine different BTVs were identified. Three isolates of serotype $11(3 / 15$; $20 \%$ ) were made and two isolates each of serotypes $1,8,12$ and $15(2 / 15 ; 13.3 \%$ each) were made. One isolate each of serotypes 2, 10, 16 and 18 were also identified (1/15; 6.7\% each). The EEV isolates were not serotyped.

\section{Discussion}

Trap sites chosen were believed to be representative of the climatic and geo-physical conditions found within each NR. However, the significance of the distribution of Culicoides across the five NRs of Zimbabwe must be interpreted with caution. It is important to realise that these five agroecological regions were characterised more than 50 years ago (Vincent \& Thomas 1960). Mugandani et al. (2012) have argued that this is misleading as it implies that the climatic conditions have remained stable over this time. Research, however, points to the contrary; Makarau (1999) and Low (2005) noted increased variability of rainfall, rain days and temperature in Zimbabwe. Most meteorological stations in Zimbabwe have shown a decline in rainfall over the past 100 years (Mugandani et al. 2012). Furthermore, Corbett and Carter (1996) noted that continued use of these agroecological regions was at odds with the political, social and agrarian reform that has taken place in Zimbabwe since Vincent and Thomas (1960) established these regions.

Caution should also be observed when interpreting absolute counts of Culicoides as there may be some variation dependent on the trap sites within each NR. The number of host animals and the distance of these animals from the trap site may also influence the numbers of Culicoides collected. Trap sites in NR II recorded the greatest diversity of Culicoides species, with 43 species identified. The highest median count of Culicoides was recorded in trap sites located within NR III. Natural region III includes the central highveld of Zimbabwe, averaging a total annual rainfall of $500 \mathrm{~mm}-700 \mathrm{~mm}$, with predominantly greyish brown clay soils and sandy loams derived from granitic rocks (Vincent \& Thomas 1960). 
High median counts of Culicoides midges were recorded in March and April, at the end of the rainy season. Numbers of adult flies steadily increase after the start of the rainy season as the availability of breeding sites increases (Musuka 1999). Similar findings have been reported previously in Zimbabwe and South Africa, with large populations of Culicoides vectors found in areas with high average annual rainfall and summer temperatures (Musuka 1999; Musuka et al. 2001; Venter, Nevill \& Van der Linde 1997). Temperature influences the abundance of Culicoides vectors through its effect on the availability of suitable breeding sites, larval development and adult mortality (Mellor \& Hamblin 2004). High environmental temperatures lead to a shorter time span between blood-feeding events and an increase in the rate of virogenesis within the adult vector, leading to earlier virus transmission, although at high temperatures the rate of adult mortality also increases (Mellor \& Hamblin 2004; Wellby et al. 1996).

Previous studies have demonstrated that soil type appears to be very important in determining the distribution and abundance of C. imicola (Meiswinkel 1998; Musuka et al. 2001). In concurrence with these previous findings, the largest numbers of $C$. imicola were found in areas with a high, moisture-retentive clay soil, whilst the lowest numbers were encountered in rapidly draining sandy soils. The biggest collections of Culicoides were obtained from a large equine stud on the outskirts of Harare. This farm was situated in a low-lying area on the banks of a major river and had clayey soils and open grassland vegetation.

This study showed that large numbers of C. imicola were collected in light traps located at sites where horses were stabled indoors at night even though some stables were fitted with protective fly screens. This suggests that $C$. imicola were still feeding successfully as they depend upon blood meals for the development of their eggs. Successful feeding may have been facilitated by the common practice of leaving the upper half of the stable door open for ventilation (Meiswinkel 1998). Horses kept out in the open at night appear to be more susceptible to midge bites than stabled horses and these outside horses may act as decoys deflecting C. imicola away from the stabled animals. If these decoys are removed or stabled, then the midges may attempt to feed on stabled animals (Meiswinkel 1998).

This study has identified 10 species of Culicoides that previously have not been recorded in Zimbabwe (Blackburn et al. 1985; Musuka 1999; Musuka \& Kelly 2000; Musuka et al. 1998, 2001; Phelps et al. 1982), bringing the total number of recognised species of Culicoides in Zimbabwe to 60. Of particular note was the identification of two additional C. imicola complex species, Culicoides loxodontis and C. miombo, which were distributed across four of the NRs of Zimbabwe. The epidemiological significance of these species as vectors of arboviruses in Zimbabwe needs further investigation, although the findings of this study significantly add to the available knowledge on the distribution of these species in southern Africa.
Musuka (1999) has shown that C. bolitinos has a widespread distribution in southern Africa. Furthermore, C. bolitinos, which was found at all five trap sites in Harare in the present survey, has been implicated in AHSV, EEV and BTV transmission in South Africa (Meiswinkel \& Paweska 1998, 2003; Venter et al. 2002) and, therefore, could play a role in the spread of the disease in Zimbabwe. In our study, the highest prevalence $(5.7 \%)$ of $C$. bolitinos was recorded in NR V (Table 2). This region is characterised by low rainfall and high environmental temperatures, although in South Africa C. bolitinos has been reported to be more abundant in the cooler mountainous regions (Meiswinkel \& Paweska 2003; Venter et al. 2002). This species breeds in the dung of cattle and buffaloes and the traps in the NR V trap site were located near a cattle pen containing 30 cattle. The trap sites also included a wildlife sanctuary in north Zimbabwe that hosts large populations of wild buffaloes (Syncerus caffer).

The distribution of Culicoides species observed during this study closely matched the sero-incidence and prevalence of AHSV, EEV, BTV and EHDV reported by Gordon (2010). In order to fully understand the role of the various Culicoides species in the transmission of arboviruses in Zimbabwe, further studies are needed to determine the vector competence of the sibling species of the C. imicola group and other Culicoides species that are potential vectors in southern Africa (Musuka et al. 1998). It has recently been demonstrated, for example, that $C$. magnus could become infected with both BTV and AHSV under laboratory conditions (Paweska, Prinsloo \& Venter 2003; Paweska, Venter \& Mellor 2002; Venter et al. 2004, 2009).

In this study, virus isolations of EEV and BTV were made only from C. imicola and C. magnus. According to Meiswinkel et al. (2004), C. miombo is suspected to be a vector of BTV. In the Harare study, however, no viral isolates were obtained from this species (although only nine individual specimens were collected and assayed). No AHSV or EHDV were isolated from any of the trapped Culicoides species despite the traps being located at horse studs and cattle farms. Low AHSV isolations from Culicoides midges were also reported by Rawlings et al. (1998) in a study conducted in Gambia, which was attributed to an extremely low infection prevalence of AHSV in the vector species of Culicoides. These observations were further authenticated by Mellor, Osborne and Jennings (1984), in Sudan, who could only make two AHSV isolations out of 7000 Culicoides specimens. Many viral, genetic and environmental factors can influence the susceptibility of Culicoides to infection and some species may be refractory to infection (Mellor et al. 1984). It is recommended, however, that large numbers of flies from many different collection sites should be collected and assayed before defining a species as refractory to infection.

The predominant serotype of BTV isolated from the Culicoides vectors was serotype 11, followed by serotypes 1, 8, 12 and 15. Previously only BTV serotype 11 has been isolated from the Culicoides vector in Zimbabwe (Blackburn et al. 1985), so this is the first time that BTV serotypes 1, 2, 8, 10, 12, 15, 16 
and 18 have been recorded in the country. The possibility that some of these additional BTV serotypes isolated may be vaccine viruses should be considered, however. The vaccine currently used in Zimbabwe is an Onderstepoort Biological Product ${ }^{\circledR}$ attenuated cell culture adapted vaccine. Serotypes 15, 16 and 18 are not included in this vaccine and thus vaccinated cattle and sheep may not be adequately protected against all BTV serotypes present in Zimbabwe. There is, therefore, a need to consider the possibility of developing a local polyvalent vaccine that protects against all the BTV serotypes circulating in Zimbabwe.

\section{Conclusion}

The greatest diversity and highest median counts of Culicoides were found in the central highveld region of Zimbabwe, which enjoys climatic and geophysical conditions favouring optimal vector breeding and larval development. The discovery of new Culicoides species in Zimbabwe adds to the existing knowledge on the distribution of Culicoides species in southern Africa. These findings, however, highlight the need for further studies to measure the vector competence of existing Culicoides species and to fully understand the role of these species in the transmission and epidemiology of arboviruses in Zimbabwe.

Furthermore, the discovery of novel BTV serotypes in this study highlights the need to review bluetongue vaccines currently in use and vaccination and control strategies being practised in Zimbabwe.

\section{Acknowledgements}

The authors would like to acknowledge the support and cooperation provided by the horse and livestock establishments in Zimbabwe that allowed Culicoides trapping to be conducted on their premises during the period under study.

\section{Competing interests}

The authors declare that they have no financial or personal relationships which may have inappropriately influenced them in writing this article.

\section{Authors' contributions}

S.J.G.G. (Massey University) wrote the manuscript and acted as project leader. G.N.M. (Biomedical Research and Training Institute), P.J.K. (Biomedical Research and Training Institute), P.S.M. (The Pirbright Institute) and C.H. (The Pirbright Institute) helped to design the project, establish and monitor the trapping sites, sort and process the vectors and assist with the virus isolation and identification. K.L. (ARC-Onderstepoort Veterinary Institute: Parasites, Vectors and Vector-borne Diseases) and E.D. (The Pirbright Institute) helped to sort, count and identify the vectors. C.B. (Massey University), C.R. (Massey University) and A.J.G. (University of Pretoria) made conceptual contributions and assisted with the data analysis, statistical work and the editing of the final manuscript.

\section{References}

Blackburn, N.K., Searle, L. \& Phelps, R.J., 1985, 'Viruses isolated from Culicoides (Diptera: Ceratopogonidae) caught at the Veterinary Research Farm, Mazowe, Zimbabwe', Journal of the Entomological Society of Southern Africa 48, 331-336.

Braverman, Y. \& Phelps, R.J., 1981, 'Species composition and blood-meal identification in samples of Culicoides (Diptera: Ceratopogonidae) collected near Salisbury, Zimbabwe in 1976-77', Journal of the Entomological Society of Southern Africa 44, 315-323.

Braverman, Y., Linley, J.R., Marcus, R. \& Frish, K., 1985, 'Seasonal survival and expectation of infective life of Culicoides spp. (Diptera: Ceratopogonidae) in Israel, with implications for bluetongue virus transmission and a comparison of the parous rate in C. imicola from Israel and Zimbabwe', Journal of Medical Entomology 22(5), 476-484. http://dx.doi.org/10.1093/jmedent/22.5.476

Coetzer, J.A.W. \& Guthrie, A.J., 2004, 'African horse sickness', in J.A.W. Coetzer \& R.C. Tustin (eds.), Infectious diseases of livestock, 2nd edn., Vol. 2, pp. 1231-1246, Oxford University Press, Cape Town.

Corbett, J.D. \& Carter, S.E., 1996, 'Using GIS to enhance agricultural planning: The example of inter-seasonal rainfall variability in Zimbabwe', Transactions in GIS 1(3), 207-218. http://dx.doi.org/10.1111/j.1467-9671.1996.tb00045.x

Crafford, J.E., Guthrie, A A.J., Van Vuuren, M., Mertens, P.P.C., Burroughs, J.N., Howell, P.G. et al., 2003, 'A group-specific, indirect sandwich ELISA for the detection of equine encephalosis virus antigen', Journal of Virological Methods 112(1-2), 129-135. http://dx.doi.org/10.1016/S0166-0934(03)00202-7

Dyce, A.L., 1969, 'The recognition of nulliparous and parous Culicoides (Diptera: Ceratopogonidae) without dissection', Journal of the Australian Entomological Society 8, 11-15. http://dx.doi.org/10.1111/j.1440-6055.1969.tb00727.x

El Hussein, A., Calisher, C.H., Holbrook, F.R., Schoepp, R.J. \& Beaty, B.J., 1989, 'Detection of bluetongue virus antigens in Culicoides variipennis by enzyme immunoassay', Journal of Clinical Microbiology 27(6), 1320-1323.

Gordon, S.J.G., 2010, 'Epizootiological studies on selected arboviruses, transmitted by Culicoides biting midges, in different species of domestic animals in Zimbabwe', MPhil thesis, Faculty of Veterinary Science, University of Zimbabwe, Harare.

Hamblin, C., Mellor, P.S. \& Boned, J., 1991, 'The use of ELISA for the detection of African horse sickness viruses in Culicoides midges', Journal of Virological Methods 34, 221-225. http://dx.doi.org/10.1016/0166-0934(91)90101-5

Hazrati, A. \& Ozawa, Y., 1965, 'Serological studies of AHS virus with emphasis on neutralization in tissue culture', Canadian Journal of Comparative Medicine 29, 173-178.

Low, S.M., 2005, Climate change and Africa, Cambridge University Press, New York. http://dx.doi.org/10.1017/СBO9780511535864

Makarau, A., 1999, 'Zimbabwe climate: Past present and future', in A. Senzanje, E. Manzungu \& P. van der Zaag (eds.), Water for agriculture: Policy and management options for the smallholder sector, pp. 3-16, University of Zimbabwe Publications, Harare.

Meiswinkel, R. \& Paweska, J., 1998, 'The 1998 outbreak of horse sickness in South Africa: A new Culicoides latreille (Ceratopogonidae) vector?', in J.W. Ismay (ed.), Fourth International Congress of Dipterology: Abstracts Volume, Oxford, UK, September 06-13, 1998, pp. 145-146.

Meiswinkel, R. \& Paweska, J.T., 2003, 'Evidence for a new field Culicoides vector of African horse sickness in South Africa', Preventative Veterinary Medicine 60, 243253. http://dx.doi.org/10.1016/S0167-5877(02)00231-3

Meiswinkel, R., 1995, 'Afrotropical Culicoides: Biosystematics of the Imicola group, subgenus Avaritia (Diptera: Ceratopogonidae), with special reference to the epidemiology of African horse sickness', MSc thesis, University of Pretoria.

Meiswinkel, R., 1998, 'The 1996 outbreak of African horse sickness in South Africa The entomological perspective', Archives of Virology, S14, 69-83. http://dx.doi. org/10.1007/978-3-7091-6823-3_8

Meiswinkel, R., Venter, G.J. \& Nevill, E.M., 2004, 'Vectors: Culicoides spp', in J.A.W. Coetzer \& R.C. Tustin (eds.), Infectious diseases of livestock, 2 nd edn., Vol. 1, pp. 93-137, Oxford University Press, Cape Town.

Mellor, P.S. \& Hamblin, C., 2004, 'African horse sickness', Veterinary Research 35, 445 466. http://dx.doi.org/10.1051/vetres:2004021

Mellor, P.S., 1993, 'African horse sickness: Transmission and epidemiology', Veterinary Research 24, 199-212.

Mellor, P.S., Boorman, J. \& Baylis, M., 2000, 'Culicoides biting midges: Their role as arbovirus vectors', Annual Review of Entomology 45, 307-340. http://dx.doi. org/10.1146/annurev.ento.45.1.307

Mellor, P.S., Osborne, R. \& Jennings, D.M., 1984, 'Isolation of bluetongue and related viruses from Culicoides spp. in Sudan', Journal of Hygiene (Cambridge) 93, 621626. http://dx.doi.org/10.1017/S0022172400065190

Mugandani, R., Wuta, M., Makarau, A. \& Chipindu, B., 2012, 'Re-classification of agroecological regions of Zimbabwe in conformity with climate variability and change', African Crop Science Journal 20(2), 361-369.

Mushi, E.Z., Isa, J.F.W., Chabo, R.G., Binta, M.G. \& Kapaata, R.W., 1998, 'Culicoides (Diptera: Ceratopogonidae) associated with horses at Mogoditshane, Gaborone, Botswana', Veterinary Research Communications 22, 295-297. http://dx.doi. org/10.1023/A:1006152500642

Musuka, G.N. \& Kelly, P.J., 2000, 'Preliminary studies into the seroprevalence of antibodies to bluetongue virus in cattle, sheep and goats in Zimbabwe', Bulletin of Animal Health and Production in Africa 48, 117-118. 
Musuka, G.N., 1999, 'Culicoides biting midges, vectors of arboviruses in Zimbabwe', MPhil thesis, Department of Applied Epidemiology, University of Hertfordshire.

Musuka, G.N., Chihota, C.M. \& Kelly, P.J., 1998, 'Faunistic list of Culicoides (Diptera: Ceratopogonidae) from Chinoyi, Zimbabwe', Zimbabwe Veterinary Journal 29(3), $87-89$.

Musuka, G.N., Meiswinkel, R., Baylis, M., Kelly, P.J. \& Mellor, P.S., 2001, 'Prevalence of Culicoides imicola and other species (Diptera: Ceratopogonidae) at eight sites in Zimbabwe', Journal of the South African Veterinary Association 72(2), 62-63. http://dx.doi.org/10.4102/jsava.v72i2.616

Mweene, A.S., Pandey, G.S., Sinyangwe, P., Nambota, A., Samui, K. \& Kida, H., 1996 'Viral diseases of livestock in Zambia', Japanese Journal of Veterinary Research 44(2), 89-105.

Oura, C.A.L., Batten, C.A., Ivens, P.A.S., Balcha, M., Alhassan, A., Gizaw, D. et al., 2012, 'Equine encephalosis virus: Evidence for circulation beyond southern Africa', Epidemiology and Infection 140, 1982-1986. http://dx.doi.org/10.1017/ S0950268811002688

Paweska, J.T., Gerdes, G.H., Woods, P.S.A. \& Williams, R. 1999, 'Equine encephalosis in southern Africa: Current situation', in U. Wernery, J.F. Wade, J.A. Mumford \& O.R. Kaaden (eds.), Proceedings of the Eighth International Conference on Equine Infectious Diseases, Dubai, UAE, March 23-26, 1998, pp. 303-305.

Paweska, J.T., Prinsloo, S.A. \& Venter, G.J., 2003, 'Oral susceptibility of South African Culicoides species to live-attenuated sero-type-specific vaccine strains of African horse sickness virus (AHSV)', Medical and Veterinary Entomology 17, 436-447. http://dx.doi.org/10.1111/j.1365-2915.2003.00467.x

Paweska, J.T., Venter, G.J. \& Mellor, P.S., 2002, 'Vector competence of South African Culicoides species for bluetongue virus serotype 1 (BTV-1) with special reference to the effect of temperature on the rate of virus replication in C. imicola and $C$. to the effect of temperature on the rate of virus replication in C. imicola and C.
bolitinos', Medical Veterinary Entomology 16, 10-21. http://dx.doi.org/10.1046/ bolitinos', Medical Veterinary

Phelps, R., Blackburn, N. \& Searle, L., 1982, 'Culicoides (Diptera: Ceratopogonidae) catches and virus isolation from them in Mukwadzi Valley, Zimbabwe', Journal of catches and virus isolation from them in Mukwadzi Valley,

Rawlings, P., Snow, W.F., Boorman, J., Denison, E., Hamblin, C. \& Mellor, P.S., 1998, 'Culicoides in relation to transmission of African horse sickness virus in The Gambia', Medical and Veterinary Entomology 12, 155-159. http://dx.doi. org/10.1046/j.1365-2915.1998.00094.x
Scacchia, M., Lelli, R., Peccio, A., Di Mattia, T., Mbulu, R.S., Hager, A.L., et al., 2009 'African horse sickness: A description of outbreaks in Namibia', Veterinaria Italiana 45(2), 265-274.

Thevasagayam, J.A., Wellby, M.P., Mertens, P.P.C., Burroughs, J.N. \& Anderson, J., 1996, 'Detection and differentiation of epizootic haemorrhagic disease of deer and bluetongue viruses by serogroup-specific sandwich ELISA', Journal of Virological Methods 56(1), 49-57. http://dx.doi.org/10.1016/0166-0934(95)01910-3

Van Ark, H. \& Meiswinkel, R., 1992, 'Subsampling of large light trap catches of Culicoides (Diptera: Ceratopogonidae)', Onderstepoort Journal of Veterinary Research 59, 183-189.

Venter, G.J., Gerdes, G.H., Mellor, P.S. \& Paweska, J.T., 2004, 'Transmission potential of South African Culicoides species for live-attenuated bluetongue virus', Veterinaria Italiana 40, 198-203.

Venter, G.J., Groenewald, D., Venter, E., Hermanides, K.G. \& Howell, P.G., 2002, 'A comparison of the vector competence of the biting midges, Culicoides (Avarita) bolitinos and C. (A.) imicola, for the Bryanston serotype of equine encephalosis virus', Medical and Veterinary Entomology 16(4), 372-377. http://dx.doi. org/10.1046/j.1365-2915.2002.00385.x

Venter, G.J., Nevill, E.M. \& Van der Linde, T.C., 1997, 'Seasonal abundance and parity of stock-associated Culicoides species (Diptera: Ceratopogonidae) in different climatic regions in southern Africa in relation to their viral vector potential', Onderstepoort Journal of Veterinary Research 64, 259-271.

Venter, G.J., Wright, I.M., Van der Linde, T.C. \& Paweska, J.T., 2009, 'The oral susceptibility of South African field populations of Culicoides to African horse sickness virus', Medical and Veterinary Entomology 23, 367-378. http://dx.doi. org/10.1111/j.1365-2915.2009.00829.x

Vincent, V. \& Thomas, R.G., 1960, An agricultural survey of southern Rhodesia: Part l: Agro-ecological survey, Government Printer, Harare.

Wellby, M.P., Baylis, M., Rawlings, P. \& Mellor, P.S., 1996, 'Effect of temperature on survival and rate of virogenesis of African horse sickness virus in Culicoides variipennis sonorensis (Diptera: Ceratopogonidae) and its significance in relation to the epidemiology of the disease', Bulletin of Entomological Research 86, 715to the epidemiology of the disease', Bulletin of Entom
720. http://dx.doi.org/10.1017/S0007485300039237

World Organisation for Animal Health (OIE), 2011, 'Sub-regional representation for southern Africa', Gaborone, Botswana, viewed 14 October 2014, from http:// www.oie.int/doc/ged/d11781.pdf 


\section{Appendix 1}

TABLE 1-A1: The distribution of all species of Culicoides collected across the five natural regions of Zimbabwe (1998-2003).

\begin{tabular}{|c|c|c|c|c|c|}
\hline \multirow[t]{2}{*}{ Culicoides species } & \multicolumn{5}{|c|}{ NR } \\
\hline & 1 & II & III & IV & v \\
\hline imicola & v & $\mathrm{V}$ & $\checkmark$ & $v$ & $v$ \\
\hline enderleini & $v$ & v & $v$ & $v$ & $\checkmark$ \\
\hline milnei & $v$ & v & v & $v$ & \\
\hline zuluensis & $v$ & $v$ & $v$ & & \\
\hline nevilli & & $v$ & $v$ & $v$ & \\
\hline leucostictus & $v$ & v & $v$ & $v$ & \\
\hline miombo & $v$ & v & & $v$ & $\checkmark$ \\
\hline pycnostictus & $v$ & $v$ & $v$ & & \\
\hline bolitinos & v & $v$ & v & $v$ & $\checkmark$ \\
\hline subschultzei & & v & $v$ & $v$ & $\checkmark$ \\
\hline coarctatus & & v & $\checkmark$ & & \\
\hline tropicalis & $v$ & $v$ & v & $v$ & \\
\hline loxodontis & & & & $v$ & $\checkmark$ \\
\hline brucei & $v$ & $v$ & $v$ & & \\
\hline nivosus & $v$ & $v$ & $\checkmark$ & $\checkmark$ & \\
\hline magnus & & $v$ & $\checkmark$ & & \\
\hline similis & & $v$ & v & $v$ & \\
\hline trifasciellus & $v$ & $v$ & & & \\
\hline engubandei & $v$ & $v$ & v & v & \\
\hline tororoensis & & & & $v$ & $v$ \\
\hline Nigripennis group & & $\checkmark$ & V & $v$ & $v$ \\
\hline sp. \#54 (p/f) & & & & v & \\
\hline sp. \#90 & & $v$ & & v & V \\
\hline neavei & $v$ & $v$ & $v$ & $v$ & \\
\hline ravus & & $v$ & $v$ & v & v \\
\hline gulbenkiani & v & v & & & \\
\hline
\end{tabular}

TABLE 1-A1 (Continues...): The distribution of all species of Culicoides collected across the five natural regions of Zimbabwe (1998-2003).

\begin{tabular}{|c|c|c|c|c|c|}
\hline \multirow[t]{2}{*}{ Culicoides species } & \multicolumn{5}{|c|}{ NR } \\
\hline & $\mathrm{I}$ & II & III & IV & V \\
\hline schultzei & & & V & $\checkmark$ & \\
\hline moreli & & & & $\checkmark$ & \\
\hline sp. \#50 & & $v$ & & $\mathrm{v}$ & v \\
\hline exspectator & & $v$ & V & V & v \\
\hline albopunctatus & & v & $\mathrm{v}$ & & \\
\hline sp. \#107 & & $\mathrm{v}$ & & $\mathrm{v}$ & \\
\hline tuttifrutti & & $v$ & & $v$ & \\
\hline sp. \#54 (d/f) & & & & $\mathrm{v}$ & v \\
\hline kanagai & & v & & $\mathrm{v}$ & \\
\hline ovalis & V & & & & \\
\hline sp. \#69 & & & $\mathrm{v}$ & & \\
\hline glabripennis & & & & & V \\
\hline fulvithorax & & $v$ & V & & \\
\hline cornutus & & $\mathrm{v}$ & & & \\
\hline moucheti & & & & $\checkmark$ & \\
\hline kibatiensis & V & $\mathrm{v}$ & & & \\
\hline perettii & & $\mathrm{v}$ & & V & \\
\hline sp. \#94 & & $v$ & & & \\
\hline dutoiti & & & V & $v$ & \\
\hline nr. angolensis & $\mathrm{v}$ & & & & \\
\hline krameri & V & v & & & \\
\hline shimoniensis & & & $\mathrm{V}$ & & \\
\hline nr. glabripennis sp. \#7 & & v & & & \\
\hline dekeyseri & & $v$ & & & \\
\hline Accraensis group & & & v & & \\
\hline
\end{tabular}

